\title{
Increased energy expenditure by a seabird in response to higher food abundance
}

\author{
Patrick G. R. Jodice ${ }^{1,6, *}$, Daniel D. Roby ${ }^{1}$, Robert M. Suryan ${ }^{1}$, David B. Irons ${ }^{2}$, \\ Kathy R. Turco ${ }^{3}$, Evelyn D. Brown ${ }^{3}$, John F. Thedinga ${ }^{4}$, G. Henk Visser ${ }^{5}$ \\ ${ }^{1}$ USGS Oregon Cooperative Fish and Wildlife Research Unit, 104 Nash Hall, Oregon State University, Corvallis, \\ Oregon 97331, USA \\ ${ }^{2}$ Migratory Bird Management, U.S. Fish and Wildlife Service, 1011 East Tudor Road, Anchorage, Alaska 99503, USA \\ ${ }^{3}$ University of Alaska, School of Fisheries and Ocean Science, Institute of Marine Science, PO Box 757220, Fairbanks, \\ Alaska 99775, USA \\ ${ }^{4}$ National Oceanographic and Atmospheric Administration, National Marine Fisheries Service, Auke Bay Laboratory, \\ 11305 Glacier Highway, Juneau, Alaska 99801, USA \\ ${ }^{5}$ University of Groningen, Centre for Isotope Research, Nijenborgh 4, Groningen, 9747 AG, The Netherlands \\ ${ }^{6}$ Present address: USGS South Carolina Cooperative Fish and Wildlife Research Unit, G27 Lehotsky Hall, \\ Clemson University, Clemson, South Carolina 29634, USA
}

\begin{abstract}
Variability in forage fish abundance strongly affects seabird behavior and reproductive success, although details of this relationship are unclear. During 1997 and 1998, we measured (1) daily energy expenditure (DEE) of 80 parent black-legged kittiwakes Rissa tridactyla at 2 colonies in Prince William Sound, Alaska (North Icy Bay and Shoup Bay), (2) abundance of surface-schooling forage fishes within the foraging range of each colony, and (3) diet composition, energy delivery rates to nestlings, and reproductive success of kittiwakes at these same colonies. Female DEE was highest at North Icy Bay in 1998, while male DEE did not differ by colony year. Abundances of Pacific herring Clupea pallasi and sand lance Ammodytes hexapterus were highest near North Icy Bay in 1998 and nearly equal in density, although Age 1+ herring comprised the majority of the diet there. Energy delivery rates to nestlings, nestling growth rates, and productivity were also highest at North Icy Bay in 1998. We suggest that female kittiwakes responded to the increased abundance of Age 1+ herring near North Icy Bay in 1998 by increasing their DEE, which in turn positively affected reproductive success. Given that adult kittiwakes have been shown to suffer decreased survival as a response to increased energy expenditure during brood rearing, the positive correlation we observed between increased abundance of a high quality food source, parental effort, and productivity is consistent with maximizing lifetime reproductive success. The lack of a response in male DEE suggests that broodrearing roles in kittiwakes differ between genders.
\end{abstract}

KEY WORDS: Daily energy expenditure $\cdot$ DEE $\cdot$ Doubly labeled water $\cdot$ Food availability $\cdot$ Blacklegged kittiwake · Pacific herring $\cdot$ Prince William Sound · Alaska

Resale or republication not permitted without written consent of the publisher

\section{INTRODUCTION}

There have only been a few investigations of the relationship between parental energy expenditure in seabirds and food availability, and hence the factors that influence this relationship remain unclear (Kitaysky et al. 2000, Jodice et al. 2002). Food availability likely plays a significant role in the regulation of adult energy expenditure because it directly affects energy procurement, foraging efficiency, and adult body condition. If productivity of seabirds is energy limited during brood rearing (Roby 1991), then shifts in food availability should affect both annual reproductive success and residual reproductive value. The extent to which 
either of these reproductive parameters is affected by a short or long term shift in food availability is likely dependent upon the parent's ability to buffer the variability in food resources by altering their level of energy expenditure and hence their level of parental effort. Although an increase in parental effort during brood rearing tends to be positively related to annual productivity in most avian species (Bryant 1991), parents must also regulate energy expenditure in light of a fitness cost that is expressed as a negative relationship between adult survival and energy expenditure during brood rearing (Deerenberg et al. 1995, Daan et al. 1996, Golet et al. 2000). In the face of this trade-off between productivity and adult survival, parents must expend energy in a manner that maximizes lifetime reproductive success and hence fitness (Williams 1966, Stearns 1992).

The manner in which parent seabirds adjust energy expenditure in response to food availability has been difficult to discern due to the difficulty of measuring both variables simultaneously and relevantly. In one of the few field studies where parental energy expenditure and food availability were both measured directly in a seabird/forage fish system, Kitaysky et al. (2000) described different relationships between parental energy expenditure and food availability for blacklegged kittiwakes Rissa tridactyla and thick-billed murres Uria lomvia nesting on the Pribilof Islands, Alaska, and suggested that there may be a species specific response in parental behavior to changes in food availability. Bryant \& Tatner (1988a) also suggested that the relationship between parental effort and food availability might not be consistent. They posited that a negative relationship would occur between parental effort and food availability when food was predictable in time or space, but that a positive relationship should occur when food availability was less predictable. Little insight was provided, however, as to the exact nature of the temporal or spatial scales of predictability with respect to food availability. Ultimately, the strength and direction of the relationship between food availability and parental effort in seabirds may be affected by the demonstrated cost of reproduction to the adult and parental investment behavior (Wiehn \& Korpimaki 1997, Golet et al. 2000).

Our goal was to determine the relationship between parental energy expenditure and food availability in a system where food can be highly ephemeral within and between locations and years. We simultaneously measured daily energy expenditure (DEE) of parent blacklegged kittiwakes at 2 colonies in Prince William Sound (PWS), Alaska, during $2 \mathrm{yr}$, and forage fish abundance within the known foraging range of each kittiwake colony during each year. Although both study colonies were located within PWS they represented distinct marine habitats and had little to no overlap in foraging ranges (Suryan et al. 2000, Ainley et al. 2003). We also assessed the importance of brood size, chick age, and adult body size on DEE, all factors known to affect avian parental effort. As part of a larger project examining reproductive energetics of seabirds in the northern Gulf of Alaska (Roby et al. 2000), we also had access to various measures of diet composition, productivity, and foraging behavior that were collected throughout each colony and concurrently with this research.

\section{MATERIALS AND METHODS}

Focal species and study sites. In Alaska, blacklegged kittiwakes nest colonially on sea cliffs and tend to lay 1 or 2 egg clutches. Kittiwakes practice biparental care during incubation and brood rearing, are monogamous, and are sexually dimorphic with respect to size (males are larger and heavier than females; Jodice et al. 2000). Plunge diving is the primary foraging technique and the technique itself and foraging bouts in general are energetically demanding (Jodice et al. 2003). Common prey of kittiwakes in PWS include Young-of-Year (YOY) and Age 1+ Pacific herring Clupea pallasi and Pacific sand lance Ammodytes hexapterus. These 2 species comprised $>70 \%$ of the diet by biomass at these 2 colonies between 1995 and 1999 (Roby et al. 2000, Suryan et al. 2000, 2002). Capelin Mallotus villosus, juvenile gadids, euphausiids (e.g. Thysanoessa spp.), and fish offal also occur in kittiwake diets in PWS (Roby et al. 2000).

We measured the DEE of kittiwakes in 1997 and 1998 at 2 colonies in PWS. The North Icy Bay colony $\left(60^{\circ} 15^{\prime} \mathrm{N}, 148^{\circ} 20^{\prime} \mathrm{W}\right.$, ca. 1500 pairs $)$ is located on a cliff in a fjord in southwestern PWS. The marine habitat in this area is characterized by fjords and bays and is subjected to open water influences from the Gulf of Alaska. The Shoup Bay colony $\left(61^{\circ} 09^{\prime} \mathrm{N}, 146^{\circ} 35^{\prime} \mathrm{W}\right.$, ca. 7500 breeding pairs) is located on an island in a fjord near Valdez, Alaska, in northeastern PWS ca. $140 \mathrm{~km}$ northeast of North Icy Bay. The marine habitat in and around Shoup Bay is characterized by fjords, bays, and inlets. Since 1985, the Shoup Bay colony has been the fastest growing colony in PWS while the North Icy Bay colony has increased, although at an annual rate less than half that of Shoup Bay (D. Irons unpubl. data).

Food availability. We conducted aerial surveys to measure the density of surface-schooling forage fish within the foraging range of each colony each year. These data were collected as part of a larger effort to investigate the relationship between kittiwake reproductive ecology and forage fish abundance. We provide only a brief description of the relevant method- 
ology herein; more detailed descriptions of the survey methodology can be found in Brown \& Moreland (2000), Norcross et al. (2001), Suryan et al. (2002), and Ainley et al. (2003).

We conducted aerial surveys during the same weeks we measured DEE (1997, $\mathrm{n}=13$ d; 1998, $\mathrm{n}=29$ d) primarily within $1 \mathrm{~km}$ from shore (see Ainley et al. 2003 for survey map) and within the known foraging range of kittiwakes from each colony (Irons 1998, Suryan et al. 2000). Surveys were conducted from fixed-wing aircraft flown at an altitude of 274 to $366 \mathrm{~m}$ and at a speed of ca. $204 \mathrm{~km} \mathrm{~h}^{-1}$. We used a calibrated cylinder to measure the surface area of each school and calculated abundance as surface area density $\left(\mathrm{m}^{2} \mathrm{~km}^{-2}\right)$. Observed fish schools were most often comprised of herring or sand lance. Schools of capelin, eulachon Thaleichthys pacificus, and juvenile salmon Oncorhynchus spp. were recorded less frequently. Schools were counted and identified to species using attributes such as school shape, size, and location. Accuracy of species identification, which was $96.1 \%$ for herring and $80.4 \%$ for sand lance (Brown \& Moreland 2000), was verified using ca. 400 validation samples derived from net samples, underwater video, and diver observations that were collected concurrently with aerial surveys. We focused our analyses on herring and sand lance because these 2 species comprise $>70 \%$ of kittiwake diet biomass at these 2 colonies (Roby et al. 2000, Suryan et al. 2000) and were the most common schools observed in PWS (Norcross et al. 2001, Ainley et al. 2003).

We estimated the proportion of herring in each of 2 age classes (YOY and Age 1+) because of the substantial difference in energy density between these classes. We defined herring age classes based on length as follows: 30 to $85 \mathrm{~mm}=\mathrm{YOY}$ and 86 to $160 \mathrm{~mm}=$ Age 1. Kittiwakes in PWS rarely consume herring $>160 \mathrm{~mm}$ (Roby et al. 2000). Age/length categories were derived from herring caught between 1996 and 1999 in PWS and hence were specific to the locale and time period of the study. We could not, however, estimate age classes of herring schools during aerial surveys. Instead, the relative density of herring in each age class was obtained by correcting surface area density estimates obtained from aerial surveys with relative biomass density $\left(\mathrm{g} \mathrm{m}^{-2}\right)$ of herring in each age class as determined from vessel based hydroacoustic surveys. Vessel based surveys were conducted specifically to provide age class estimates of herring observed during aerial surveys and in the same locations and during the same time periods as the aerial surveys (Thedinga et al. 2000). In brief, biomass density estimates were derived from hydroacoustic surveys as follows: (1) the number of herring in encountered schools (number $\mathrm{m}^{-3}$ ) was estimated based on the relationship of acoustic target strength to fish length using a species specific, acoustic target strength/length regression equation; (2) biomass density of herring $\left(\mathrm{g} \mathrm{m}^{-2}\right)$ was estimated from the number of fish in the school based on the relationship of body mass to length using a species specific, length-weight regression equation (Thedinga et al. 2000). Biomass volume estimates $\left(\mathrm{g} \mathrm{m}^{-3}\right)$ were converted to biomass density estimates $\left(\mathrm{g} \mathrm{m}^{-2}\right)$ by integrating the results over the depth of the sampled water column (i.e. that portion of the water column occupied by the school). To arrive at the corrected surface area density values for herring in each age class we then multiplied the surface area density of herring obtained from aerial surveys by the relative proportion of herring biomass in each size class obtained from hydroacoustic surveys. We report the percentage of total herring surface area density consisting of each age class.

Energy expenditure. We used the doubly labeled water (DLW) technique (Lifson \& McClintock 1966) to measure $\mathrm{CO}_{2}$ production, and hence DEE, of parent kittiwakes. We measured DEE from 17 to 21 July 1997 and from 11 to 14 July 1998 at Shoup Bay, and from 24 to 27 July 1997 and 18 to 22 July 1998 at North Icy Bay. We used noose poles and nest snares to capture adults at their nest sites during daylight hours. Although capture was restricted to accessible nests, we captured individuals from most sections of both colonies. We never sampled mates from the same pair. We measured length of head plus bill $( \pm 0.1 \mathrm{~mm}$ measured from the tip of the bill to the posterior ridge formed by the parietal-supraoccipital junction), flattened wing length $( \pm 1.0 \mathrm{~mm})$, tarsus length $( \pm 0.1 \mathrm{~mm})$, and body mass ( $\pm 0.1 \mathrm{~g}$ using an Ohaus triple beam balance) for each bird. We determined the sex of each bird based on morphometric models that were ca. 95\% accurate and incorporated our measures of headbill, flattened wing and tarsus length (Jodice et al. 2000).

Captured kittiwakes were given an intra-peritoneal injection of $0.8 \mathrm{ml}$ of a mixture of DLW $\left(59.0 \%{ }^{18} \mathrm{O}\right.$, $34.4 \%{ }^{2} \mathrm{H}$ ) immediately after capture. This dosage allowed for collection of blood samples up to $52 \mathrm{~h}$ postequilibration, with ${ }^{18} \mathrm{O}$ levels sufficiently elevated above background level (i.e. $\geq 0.02$ atom $\%$ ) to allow for calculation of individual-specific fractional ${ }^{18} \mathrm{O}$ turnover rates with sufficient accuracy. The mean time allowed for equilibration of isotopes was $77.8 \pm$ 19.9 min and birds were maintained in a calm environment during this time. Following equilibration we collected an initial $100 \mu \mathrm{l}$ blood sample from the brachial vein, visually assessed the physical condition of the bird, and then released it within $200 \mathrm{~m}$ of the colony. Blood samples were immediately flame sealed in nonheparinized, micro-hematocrit tubes and refrigerated at ca. $5^{\circ} \mathrm{C}$ until analyzed. Injected kittiwakes were 
recaptured on their nests 24 to $51 \mathrm{~h}$ post release, weighed, and a final blood sample collected. We also captured and bled, but did not inject, 6 adult kittiwakes in each colony in each year to establish background isotope levels.

We expressed $\mathrm{CO}_{2}$ production rates on a whole animal basis $\left(\mathrm{kJ} \mathrm{d}^{-1}\right)$ based upon equations in Speakman (1997). We used an energetic equivalent of $27.33 \mathrm{~kJ} \mathrm{l}^{-1}$ $\mathrm{CO}_{2}$ respired, an appropriate conversion factor for a protein and lipid rich diet, to convert mass specific rates of $\mathrm{CO}_{2}$ production to whole animal rates of daily energy expenditure $\left(\mathrm{kJ} \mathrm{d}^{-1}\right)$. Details pertaining to isotope analysis, calculation of energy expenditure rates, and calculation of total body water (TBW) \% are identical to those described in Jodice et al. (2002).

Colony specific data. We determined diet composition of kittiwakes by collecting regurgitations $(\mathrm{n}=150)$ from parents and nestlings throughout each colony each year. Regurgitations were weighed on a top loading balance $( \pm 0.01 \mathrm{~g})$ in the laboratory, sorted by species, and each identifiable prey item measured for standard length $( \pm 1 \mathrm{~mm})$. Taxonomic composition of each sample was determined from gross morphological characteristics. For partially digested prey items, an estimate of standard length was made by matching fragments to reconstruct the whole body where possible. Otoliths were removed from heads of fish to serve as species identification vouchers and, in the case of partially digested fish, to estimate standard length using species specific regression relationships of otolith length versus standard length. We categorized identifiable prey into age classes based on documented size-age class relationships. Detailed descriptions of these methods can be found in Roby et al. (2000) and Suryan et al. (2002).

We estimated the average energy delivery rate to nestlings $\left(E D R ; \mathrm{kJ}_{\text {nest }}{ }^{-1} \mathrm{~d}^{-1}\right)$ during chick rearing for each colony year as the product of mean meal delivery rate, mean meal size, and mean energy density of the meal ( $\mathrm{kJ} \mathrm{g}^{-1}$ wet mass). The component data for the EDR estimate were collected in kittiwake chicks aged 10-32 d post-hatch (dph), similar to the age of chicks used in this study. We measured meal delivery rates to nestlings (meals nest ${ }^{-1} \mathrm{~d}^{-1}$ ) by observing clustered groups of active nests and by tallying the number of meal deliveries observed (Roby et al. 2000, Suryan et al. 2002). We calculated average annual meal mass as the average of all regurgitations described above (Roby et al. 2000, Suryan et al. 2002). We determined the proximate composition of these same meals and measured their energy density. Detailed descriptions of these methods can be found in Anthony et al. (2000) and Roby et al. (2000).

Wind speed was assessed as the primary climate factor that might contribute to spatio-temporal variability in DEE. This variable has been shown to affect energy expenditure of seabirds (Gabrielsen et al. 1987, Furness \& Bryant 1996) especially during foraging bouts, which account for the greatest proportion of kittiwake DEE during brood rearing (Jodice et al. 2003). We obtained bi-hourly measures of wind speed from 2 weather buoys within the foraging ranges of each colony for each day that kittiwakes were dosed. One buoy was located in northeastern PWS near Shoup Bay and the other was located in southwestern PWS near North Icy Bay (http://www.ndbc.noaa.gov/Maps/ Alaska_inset.shtml).

Statistical analyses. A backward elimination, generalized linear model was used to assess the response of DEE to colony (North Icy Bay or Shoup Bay), year (1997 or 1998), brood size (1 or 2 chick), adult body size (the sum of the standardized values for lengths of headbill, flattened wing, and tarsus; Jodice et al. 2000), and chick age (age in dph of the older of 2 chicks in a 2 chick brood, or the age of the singleton in a 1 chick brood, estimated from regressions of known ages on wing length; R. M. Suryan \& P. G. R. Jodice unpubl. data). At the time of the experiment, the mean age of nestlings was $18.1 \pm 0.7 \mathrm{dph}$, although chick age was treated as a categorical variable (0 to 10, 11 to 20, $>21 \mathrm{dph}$ ) because it was estimated and not measured precisely. We did not include body mass as an independent variable because it can exhibit substantial short-term variation based on the fullness of the gut. Instead, we included body size, which is invariant during the study period. We did not include TBW\% (which has a strong negative relationship with body fat content and thus serves as a useful index for energy reserves; Schoeller et al. 1980, Speakman et al. 2001) as an independent variable because it was significantly related to colony and year (see 'Results'). Food abundance also was not included in the models because the data collection and analysis methods resulted in only a single estimate of prey abundance for each colony year (Brown \& Moreland 2000). We included all 2 and 3 way interactions among the variables colony, year, and brood size.

Therefore, the initial full model included colony, year, brood size, chick age, adult body size, and colony $x$ year. A larger model was not developed because we attempted to keep the ratio of sample size to model parameters close to the recommended ratio of 10:1 (Neter et al. 1990). At each step of the elimination process, the variable with the highest $\mathrm{p}$-value was eliminated if that $p$-value $>0.15$. The process was ceased when all variables in the model had a $p$-value $\leq 0.10$. We conducted regression models separately for each sex because we found that gender was strongly related to other explanatory variables, that the sample size for gender was skewed among colonies and years, and 
that such an approach provided a more efficient means to seek different responses of each sex to the variables examined.

Residuals were assessed for homoscedasticity and normality using Kolmogorov-Smirnov distribution tests, quantile-quantile plots, and frequency distributions. Untransformed data were used unless noted otherwise. Means and regression coefficients are reported as \pm 1 SE unless stated otherwise. We report $p$-values throughout.

\section{RESULTS}

\section{Food availability}

The size of observed fish schools ranged from ca. 5 to $>700 \mathrm{~m}^{2}$ for herring and from ca. 5 to $>350 \mathrm{~m}^{2}$ for sand lance. The species specific error rates for estimates of surface area density of herring and sand lance were 15.2 and 30.9\%, respectively (Brown \& Moreland 2000). Abundance of forage fish was highest near North Icy Bay in 1998 and the abundance of herring and sand lance was similar (Fig. 1a). Herring was more abundant near North Icy Bay in 1998 compared to all other colony years (Fig. 1a). Age 1+ herring were far more common at North Icy Bay in 1998 (85.3\% of total surface area density) compared to 1997 (7.0\%) and at Shoup Bay in 1998 (76.5\%) compared to 1997 (4.7\%). Herring comprised the majority of the diet at both colonies in 1998 (Fig. 1b) and also contributed a vast majority of the energy delivered to nestlings at both colonies in 1998 (Fig. 1c). The correlation between the surface area density of a prey type and the amount of energy delivered to nestlings from that prey type was strongly positive for Age 1+ herring ( $\mathrm{r}=0.94)$, moderately positive for YOY herring $(\mathrm{r}=0.58)$, and weakly negative for sand lance $(\mathrm{r}=-0.27)$.

\section{Energy expenditure}

We injected 100 parent kittiwakes with DLW (25 adults colony ${ }^{-1} \mathrm{yr}^{-1}$ ) and recaptured 81 of these birds. None of the injected birds abandoned their broods during our study. DEE measurement intervals ranged from 23.7 to $51.4 \mathrm{~h}$. There was no relationship between measurement interval and DEE $\left(t_{78}=0.002, \mathrm{p}=0.9\right)$. One injected female from Shoup Bay in 1998 was considered an outlier (DEE was 8.6 SDs > female mean) and omitted from all further analyses.

DEE ranged from 461 to $1179 \mathrm{~kJ} \mathrm{~d}^{-1}$. The mean DEE of females $\left(772 \pm 22 \mathrm{~kJ} \mathrm{~d}^{-1}, \mathrm{n}=50\right)$ was less than that of males $\left(872 \pm 24 \mathrm{~kJ} \mathrm{~d}^{-1}, \mathrm{n}=30\right)$ when data were pooled among all colonies and years $\left(t_{78}=2.9, \mathrm{p}=0.005\right)$. Mass
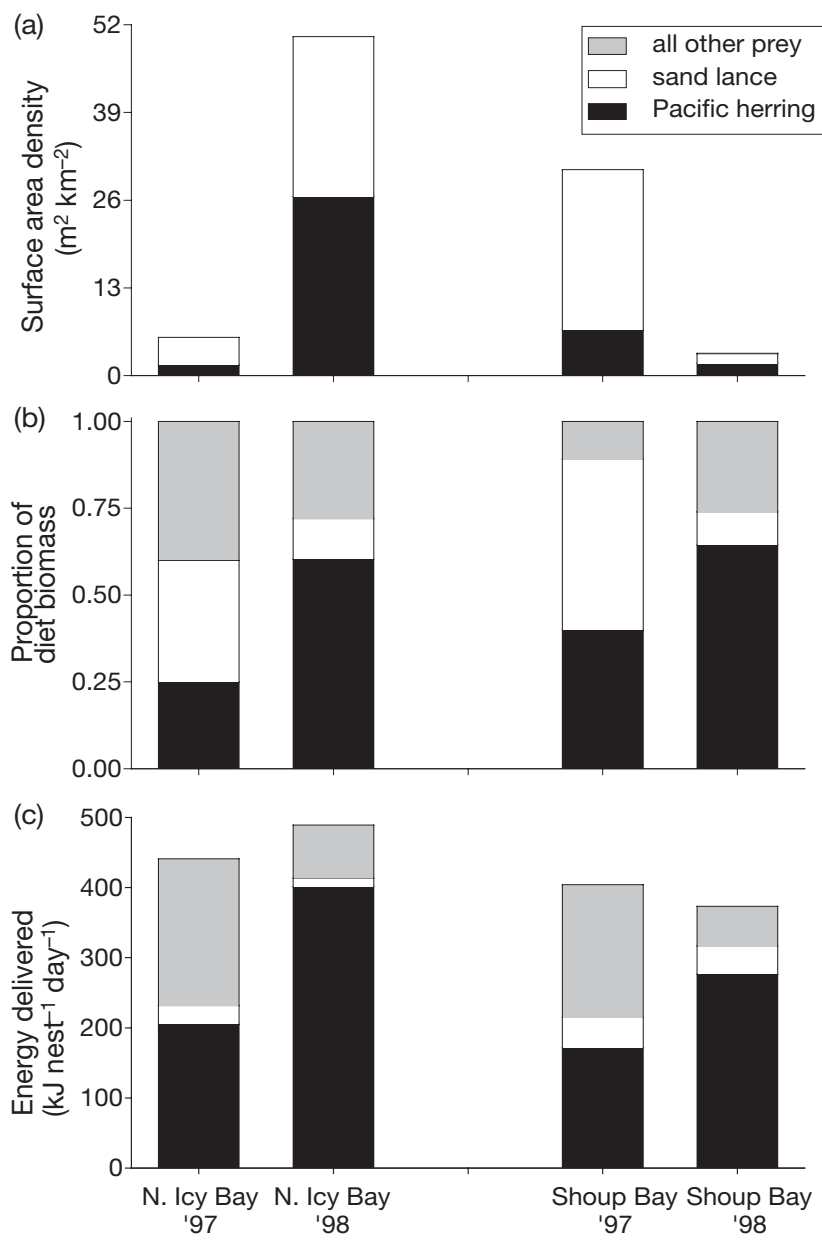

Fig. 1. Abundance of forage fish and diet composition of black-legged kittiwakes raising young at the North Icy Bay and Shoup Bay colonies in Prince William Sound during 1997 and 1998. (a) Surface area density $\left(\mathrm{m}^{2} \mathrm{~km}^{-2}\right.$; derived from aerial surveys) of Pacific herring and sand lance within the foraging range of parent kittiwakes nesting at the 2 colonies in the 2 yr. (b) Proportion of total food biomass for kittiwakes that consisted of Pacific herring, sand lance, and all other prey by colony and year, as determined by analysis of food regurgitations from nestlings and adults. (c) Energy delivery rate by parent kittiwakes to their broods $\left(\mathrm{kJ}_{\text {nest }}{ }^{-1} \mathrm{~d}^{-1}\right)$, separated into Pacific herring, sand lance, and all other forage fish types, by colony and year

specific DEE of females $\left(2132 \pm 60 \mathrm{~kJ} \mathrm{~kg}^{-1} \mathrm{~d}^{-1}\right)$ was nearly identical to that of males $\left(2101 \pm 50 \mathrm{~kJ} \mathrm{~kg}^{-1} \mathrm{~d}^{-1}\right)$.

Daily energy expenditure of female kittiwakes was significantly related to colony $\times$ year and brood size (final model $F_{4,45}=2.7, \mathrm{p}=0.04, \mathrm{R}^{2}=0.20$ ). The effect of colony $\times$ year on female DEE was significant $\left(F_{1,45}=\right.$ $4.1, \mathrm{p}=0.047)$. Female DEE was significantly higher $\left(t_{48}=2.0, \mathrm{p}=0.02 ;\right.$ Fig. 2$)$ at North Icy Bay during 1998 $\left(868 \pm 44 \mathrm{~kJ} \mathrm{~d}^{-1}, \mathrm{n}=11\right)$ compared to all other colony years $\left(746 \pm 24 \mathrm{~kJ} \mathrm{~d}^{-1}, \mathrm{n}=69\right)$. DEE of females also was significantly higher $\left(F_{1,45}=4.1, \mathrm{p}=0.048\right)$ for individuals with 2 chick broods $\left(815 \pm 45 \mathrm{~kJ} \mathrm{~d}^{-1}, \mathrm{n}=18\right)$ com- 


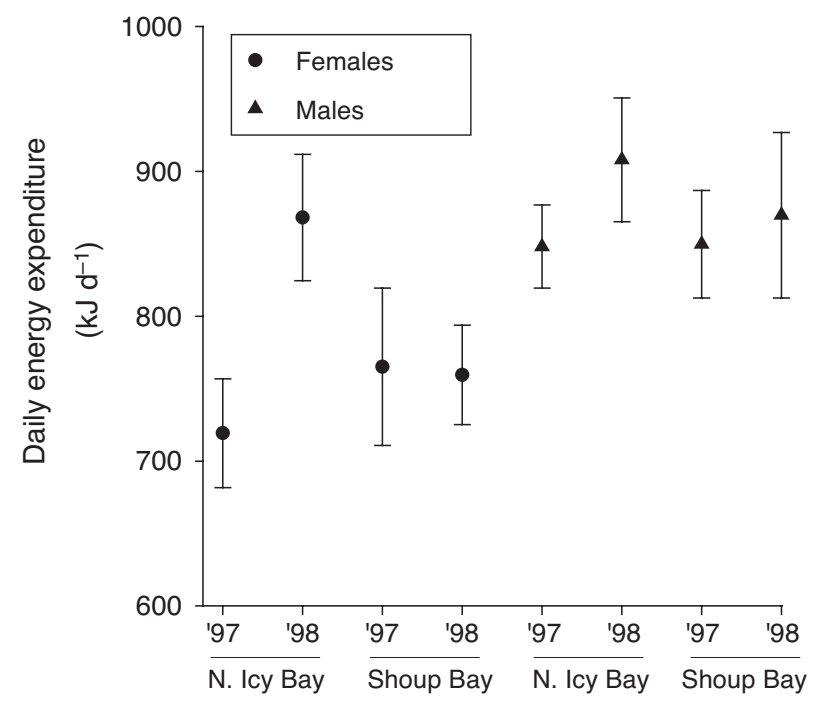

Fig. 2. Rissa tridactyla. Mean ( $\pm 1 \mathrm{SE})$ daily energy expenditure $\left(\mathrm{kJ} \mathrm{d}^{-1}\right)$ by colony and year of female and male black-legged kittiwakes raising young at the North Icy Bay and Shoup Bay colonies in Prince William Sound during 1997 and 1998

pared to 1 chick broods $\left(749 \pm 23 \mathrm{~kJ} \mathrm{~d}^{-1}, \mathrm{n}=32\right)$. The interaction term of colony, year, and brood size was eliminated from the female model prior to the final step $\left(F_{2,42}=0.9, \mathrm{p}=0.4\right)$. Daily energy expenditure of male kittiwakes was significantly related only to body size $\left(\right.$ Male DEE $=750.7+26.8( \pm 10.4) \times$ body size; $F_{1,28}=$ $\left.6.6, p=0.02, R^{2}=0.19\right)$. Male DEE did not differ by colony, year, or their interaction (Fig. 2) and none of these main variables were included in the final regression model.

We used ANCOVAs to assess the relationship between mean DEE for each colony year and the surface area density of both herring and sand lance; sex was used as the categorical term in each model. For the herring model, there was a marginal difference between the sexes in the slope of the regression of DEE on surface area density $\left(F_{1,4}=6.7, p=0.06\right.$; Fig. 3$)$, so separate models were analyzed for each sex. Female DEE was significantly and positively related to surface area density of herring (Female DEE $=729.9+5.2$ $( \pm 0.9) \times$ herring density; $\left.t_{1,3}=5.5, \mathrm{p}=0.03, \mathrm{R}^{2}=0.91\right)$. The relationship between male DEE and herring density was not significant $\left(t_{1,3}=2.7, \mathrm{p}=0.11\right)$. For the sand lance model, there was no significant difference between the sexes for the slope of the regression of DEE on density $\left(F_{1,4}=0.7, \mathrm{p}=0.4\right)$, nor was there a significant relationship between DEE and the density of sand lance when data were pooled among the sexes $\left(F_{1,4}=2.0, \mathrm{p}=0.2\right)$.

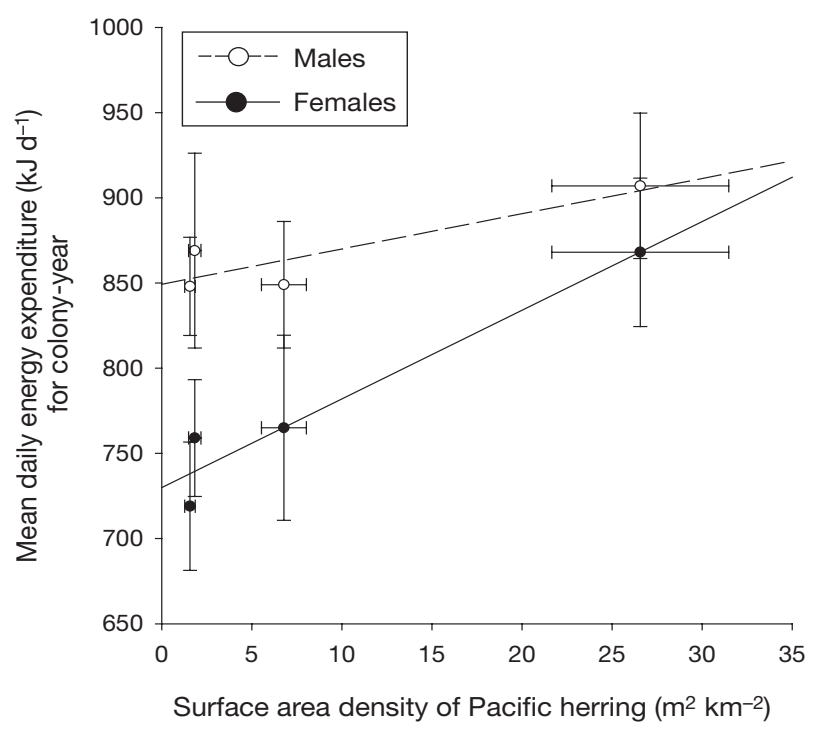

Fig. 3. Rissa tridactyla. Relationship of colony-year means $( \pm 1 \mathrm{SE})$ of daily energy expenditure (DEE, $\mathrm{kJ} \mathrm{d}^{-1}$ ) in female and male black-legged kittiwakes raising young at the North Icy Bay and Shoup Bay colonies in Prince William Sound during 1997 and 1998 to surface area density $\left(\mathrm{m}^{2} \mathrm{~km}^{-2}\right)$ of Pacific herring. Sample sizes for measures of DEE range from 11 to 15 for females and from 3 to 10 for males (see Fig. 2). See 'Results' for explanation of error bars for surface area density of herring

\section{Colony and individual measures}

There were moderate to strong differences between genders in body mass, TBW\%, and nestling age (Table 1). The proportion of 1 chick broods for injected males $(63.3 \%)$ was nearly identical to that of injected females $(64.0 \%)$.

There was no effect of colony, year, or colony $\times$ year on males for body mass, body size, or TBW\% $\left(F_{1,26} \leq\right.$ $2.2, \mathrm{p}>0.15$ for each independent variable within each factorial ANOVA). Chick age was slightly greater $\left(F_{1,26}\right.$ $=3.7, \mathrm{p}=0.07)$ for males in $1997(19.0 \pm 1.6 \mathrm{~d}, \mathrm{n}=12)$ compared to $1998(14.9 \pm 1.1 \mathrm{~d}, \mathrm{n}=18)$. The proportion of 2 chick broods for males in our study ranged from 20 to $67 \%$ and was greatest at North Icy Bay in 1997.

There was no effect of colony, year, or colony $\times$ year on female body size $\left(F_{1,46}=1.6, \mathrm{p}>0.21\right.$ for each inde-

Table 1. Rissa tridactyla. Body measures and brood status of male and female blacklegged kittiwakes raising young at the North Icy Bay and Shoup Bay colonies in Prince William Sound, Alaska, July 1997 and 1998. Means ( \pm SE) are shown

\begin{tabular}{|lccc|}
\hline Variable & $\begin{array}{c}\text { Female } \\
(\mathrm{n}=50)\end{array}$ & $\begin{array}{c}\text { Male } \\
(\mathrm{n}=30)\end{array}$ & Significance \\
\hline Body mass (g) & $363.1 \pm 3.1$ & $414.3 \pm 5.3$ & $t_{78}=8.9, \mathrm{p}<0.0001$ \\
Total body water \% & $62.2 \pm 0.3$ & $61.2 \pm 0.3$ & $t_{78}=2.1, \mathrm{p}=0.04$ \\
Nestling age (d) & $19.0 \pm 0.9$ & $16.5 \pm 1.0$ & $t_{78}=1.8, \mathrm{p}=0.08$ \\
\hline
\end{tabular}


pendent variable). Female body mass was slightly greater $\left(F_{1,46}=3.0, \mathrm{p}=0.08\right)$ at North Icy Bay $(371.5 \pm$ $4.2 \mathrm{~g}, \mathrm{n}=26)$ compared to Shoup Bay $(354.0 \pm 4.1 \mathrm{~g}, \mathrm{n}=$ 24). TBW\% of females was significantly lower $\left(F_{1,46}=\right.$ 16.7, $\mathrm{p}<0.001)$ at North Icy Bay in 1998 (59.8 $\pm 0.7, \mathrm{n}=$ 11) compared to all other colony years $(62.8 \pm 0.2, \mathrm{n}=$ 39). Nestlings were older for injected females at North Icy Bay in $1997(25.1 \pm 1.4 \mathrm{~d}, \mathrm{n}=15)$ compared to injected females at all other colony years (range of means was $15.1 \pm 2.1$ to $18.2 \pm 1.4 \mathrm{~d}_{i} F_{1,46}=6.1, \mathrm{p}=$ 0.02). The proportion of 2 chick broods for females in our study ranged from 25 to $53 \%$ and was greatest at North Icy Bay in 1997.

Average wind speed during the weeks of DEE measurement was $3.6 \pm 0.16 \mathrm{~m} \mathrm{~s}^{-1}$ and did not vary by location, year, or their interaction (model $F_{3,186}=1.2$, $\mathrm{p}=0.3)$.

\section{DISCUSSION}

The aerial survey data we collected provided a useful metric of food availability for foraging kittiwakes (Ainley et al. 2003). We conducted forage fish surveys primarily in the nearshore zone of PWS, which is both the primary habitat for YOY and Age 1+ herring and sand lance (Norcross et al. 2001), and the primary foraging and commuting habitat of kittiwakes (Irons 1992, Maniscalco et al. 1998, Ainley et al. 2003). Ford et al. (1998) found a strong, positive correlation between the location of foraging kittiwakes in PWS and the location of surface schooling forage fishes. Aerial surveys also recorded a wide range of school sizes, including schools $<5 \mathrm{~m}^{2}$ in area. Although kittiwakes do forage on individual prey and small schools that may not be observed during aerial forage-fish surveys, the impact of this behavior on our results appears to be minimal. For example, Ainley et al. (2003) found no relationship between kittiwake occurrence in PWS and the size of fish schools, and rarely observed kittiwakes foraging in PWS waters where fish schools were not observed. These observations suggest that our measures of forage fish abundance were relevant to foraging kittiwakes and thus provide a reasonable measure of food availability in this system.

\section{Energy expenditure in parent seabirds}

Daily energy expenditure of female kittiwakes was higher at North Icy Bay in 1998 compared to all other colony years. In contrast, male DEE did not vary with colony, year, or their interaction. The colony year effect observed in females may be a response to a variety of factors. Here we review 4 factors that can affect energy expenditure in parent seabirds; brood size, nestling age, climate, and food availability.

We observed a positive relationship between brood size and energy expenditure of female kittiwakes. A positive relationship between energy expenditure and brood size has been documented previously for this species (Gabrielsen et al. 1987, Golet et al. 2000, Fyhn et al. 2001), although not specific to one gender as suggested by our results. Therefore, differences in brood sizes among colony years could affect DEE. During our study, however, there was a far greater proportion of 1 chick (72\%) compared to 2 chick (28\%) broods for females at North Icy Bay in 1998 and a greater proportion of 2 chick broods at Shoup Bay (33\%) and North Icy (53\%) Bay in 1997 compared to North Icy Bay in 1998. It is therefore unlikely that increased brood size contributed to the elevated female DEE observed at North Icy Bay in 1998. Kittiwake DEE also may be positively related to nestling age (Fyhn et al. 2001). The mean age of nestlings from females in our study at North Icy Bay in 1998 was no different, however, from mean nestling ages for females at Shoup Bay in 1997 or 1998.

Seabird DEE can also be affected by local weather patterns, especially during energetically demanding foraging bouts. Significant relationships between wind speed and DEE have been demonstrated in northern fulmars Fulmarus glacialis, little auks Alle alle, and black-legged kittiwakes (Gabrielsen et al. 1987 , Gabrielsen et al. 1991, Furness \& Bryant 1996). During the course of our study, however, wind speed recorded within the foraging areas of each colony did not differ significantly among colonies or years.

We suggest that the elevation in DEE of female kittiwakes at North Icy Bay in 1998 occurred in response to a localized increase in the density of Age 1+ herring. This prey type is characterized by high energy density, high lipid content, and large size (Anthony et al. 2000). As such, Age 1+ herring represents the highest quality food item typically available to kittiwakes in PWS. Although sand lance and herring were nearly equal in abundance near North Icy Bay in 1998 (Fig. 1a), herring comprised a greater proportion of the diet (Fig. 1b) and of the energy delivered to nestlings there (Fig. 1c). Kittiwakes in PWS often display improved reproductive success when Age 1+ herring dominate the diet (Roby et al. 2000, Suryan et al. 2002) and this appeared to be the case at North Icy Bay in 1998. For example, meal delivery rates at North Icy Bay in 1998 (4.8 meals nest ${ }^{-1}$ $\mathrm{d}^{-1}$ ) were the highest measured at either colony from 1995 through 1999 (ranging from 2.7 to 4.0 meals nest $^{-1}$ $\mathrm{d}^{-1}$ for all other colony years); nestling growth rates at North Icy Bay in $1998\left(17.5 \pm 0.5 \mathrm{~g} \mathrm{~d}^{-1}\right)$ were the highest measured at either colony from 1995 through 1999 (ranging from 13.9 to $16.9 \mathrm{~g} \mathrm{~d}^{-1}$ for all other colony 
years); and productivity at North Icy Bay in 1998 (0.63 \pm 0.12 chicks fledged per nest) was the highest measured at either colony in 1997 or 1998 (ranging from 0.46 to 0.50 chicks fledged per nest) and the second highest measured at either colony from 1995 through 1999 (ranging from 0 to 0.7 chicks fledged per nest; Roby et al. 2000). High levels of reproductive effort and reproductive success thus coincided with increased availability of Age 1+ herring.

In contrast, kittiwakes at Shoup Bay in 1997 did not display similarly high levels of reproductive effort, reproductive success, or DEE despite a relatively high abundance of sand lance near the colony. Kittiwakes at Shoup Bay tend not to exhibit high levels of productivity, growth rates, or meal delivery rates when sand lance is the dominant forage fish in the region (Suryan et al. 2000, 2002). This may be due in part to spatial and temporal inconsistencies in availability particular to sand lance. For example, sand lance typically are located further from the Shoup Bay colony compared to herring. This leads to longer foraging trips and lower rates of meal delivery during times of sand lance dominance (Suryan et al. 2000).

An increase in energy expenditure concomitant with increased food availability is consistent with predictions from optimal foraging models especially in systems with highly ephemeral food resources (Bryant \& Tatner 1988b). Central-place foragers, such as parent seabirds raising nidicolous young, should increase foraging effort and hence energy expenditure when such increases are rewarded by a similar or greater increase in net energy gained (Norberg 1977, Davis et al. 1999). For example, Bautista et al. (1998) demonstrated that European starlings Sturnus vulgaris foraging under conditions of experimentally improved food availability elevated both their rates of energy expenditure and energy intake, although the duration of daily foraging was actually reduced. In kittiwakes, energy expenditure rates are strongly and positively related to the proportion of time adults spend foraging (Jodice et al. 2003) and foraging effort and rates of meal delivery are positively related to natural levels of prey availability (Hamer et al. 1993, Suryan et al. 2000). In fact, meal delivery rates to nestlings during our study were 20 to $70 \%$ higher at North Icy Bay in 1998 compared to all other colony years (Roby et al. 2000). Therefore, higher levels of DEE in females during 1998 at North Icy Bay are consistent with an increase in prey density, an improvement in prey quality, and an increase in meal delivery rates to nestlings.

A positive response in parental effort of female kittiwakes to increased food availability also is consistent with the need for parents to maximize their lifetime reproductive success given the opposing relationships observed between parental effort and productivity (posi- tive relationship) and between parental effort and survival (negative relationship). For example, Golet et al. (2000) found a negative relationship between energy expenditure of parent kittiwakes and survival. Parents that had their broods removed had lower rates of energy expenditure compared to parents raising broods, and subsequent survival rates were higher in the brood deprived population compared to those of the control population. This suggests that kittiwakes raising nestlings should increase rates of energy expenditure, and hence incur a potential survival cost, only if doing so also leads to increased productivity. This is most likely to occur when food availability and quality are high enough to support increased meal and energy delivery rates, as was the case at North Icy Bay in 1998. In this manner, lifetime reproductive success would be less likely to be compromised by an increase in parental effort that would in turn lead to decreased rates of survival.

Food availability and energy expenditure have rarely been measured simultaneously in any avian system (Tinbergen \& Dietz 1994, Brodmann et al. 1997, Kitaysky et al. 2000). Although numerous studies have demonstrated that parent seabirds adjust time-activity budgets and meal delivery rates to nestlings in response to shifts in food availability (e.g. Burger and Piatt 1990, Monoghan et al. 1994, Zador \& Piatt 1999), few have measured energy expenditure in parent seabirds directly. Kitaysky et al. (2000) did measure abundance of forage fish and parental energy expenditure and reported a different response between these 2 factors in 2 seabird species; DEE of thick-billed murre parents did not differ between years while DEE in kittiwake parents increased with a decrease in food availability between years. This led the authors to suggest that the relationship between parental effort and food availability may be species specific. Kitaysky et al. (2000), however, did not determine diet composition during this 2 yr period nor did they determine the gender of the individuals for whom DEE was measured. It appears, therefore, that the relationship between DEE and food availability in parent seabirds (1) may differ between genders, (2) may differ not only between species but also between populations within a species, and (3) may be affected by the interaction of diet composition and diet quality.

\section{Gender differences in energy expenditure}

We suggest that the lack of a colony year effect on DEE of male kittiwakes may be due to gender specific differences in brood rearing roles. For example, our data suggest a gender specific response in energy expenditure to brood size, which has not been reported previously for kittiwakes (Gabrielsen et al. 1987, 
Thompson et al. 1998, Golet et al. 2000, Jodice et al. 2002). A gender specific response to brood size or brood mass has been reported for other avian species (e.g. house martins Delichon urbica, Hails \& Bryant 1979; European kestrels Falco tinnunculus, Deerenberg et al. 1995; and pied flycatchers Ficedula hypoleuca, Moreno et al. 1995), and has been attributed to differences in reproductive roles between the sexes (Hails \& Bryant 1979). Differences in reproductive roles between the genders have been suggested for kittiwakes in previous studies. Thompson et al. (1998) suggested that male kittiwakes invested more in nest site procurement and defense compared to females and that the higher energy expenditure of males in their study was due at least in part to males expending greater energy while away from the nest. Fyhn et al. (2001) observed that, in mated pairs of kittiwakes, females were more likely to expend energy at a greater rate than were males. Similar to results observed in this study, Jodice et al. (2002) reported that energy expenditure rates of female kittiwakes responded more strongly to supplemental feeding during brood rearing compared to males and that sex specific differences in behavior not related to brood attendance (e.g. foraging and intra-specific interactions while at the colony) likely accounted for the weaker male response. Roberts \& Hatch (1993) reported that meal delivery rates of male and female kittiwakes differed between years of contrasting food availability, and that females fed chicks more frequently than males when food availability was higher. All of the above results suggest that male and female kittiwakes may exhibit different roles during chick rearing and that they may respond differently to shifts in food availability.

\section{Sustained metabolic scope}

Drent \& Daan (1980) proposed that, even under dynamic environmental conditions, parent birds would maintain DEE $\leq 4.0 \times$ basal metabolic rate $(\mathrm{BMR})$, although revisions suggest 5.0 to $5.7 \times \mathrm{BMR}$ is more appropriate (Weathers \& Sullivan 1989, Peterson et al. 1990). Intraspecific, intercolony comparisons of DEE in seabirds provide excellent opportunities to assess the concept of a sustained metabolic scope. For example, DEE of least auklets Aethia pusilla ranged only from 2.9 to $3.1 \times$ BMR among 3 colonies in the Bering Sea despite substantial differences in foraging radii from the colony, leading the authors to suggest that energy expenditure may be 'relatively invariant' within species during the breeding season (Obst et al. 1995). The range in mean DEE we measured ( 2.3 to $2.9 \times \mathrm{BMR}$ ) was below the proposed ceilings for sustained meta- bolic scope and thus may also be considered relatively invariant (sensu Obst et al. 1995). Nonetheless, the colony year differences that we observed in female DEE were positively related to reproductive effort and performance, indicating that slight alterations in energy budgets may have important reproductive implications. A relatively narrow range in DEE values also was observed in a brood removal experiment with kittiwakes (Golet et al. 2000). There, DEE of individuals whose broods were removed (ca. $2.2 \times$ BMR) was significantly less compared to control birds (ca. $2.7 \times$ BMR), although the former group accrued a survival benefit. Results from our study and those of Golet et al. (2000) suggest that changes in DEE should be examined relative to some measure of fitness as individuals may experience costs and benefits to survival while maintaining $\mathrm{DEE}<4.0 \times \mathrm{BMR}$.

Acknowledgements. We are grateful for field assistance from M. Becker, B. Bilotta, B. Henry, S. Holzwarth, A. Kaplan, M. Kaufman, K. Mosher, E.-M. Muecke, J. Rothermel, T. Sauer, G. Spencer, C. Van-Hemert, and R. Wilhite. B. Verstappen and T. Dijkstra skillfully performed the isotope analyses. We thank D.C. Duffy and B.A. Wright for overall project assistance. We thank H. Ellis, M. Chappell, P. Hodum, and anonymous reviewers who commented on previous versions of this manuscript. This research was supported in part by a research grant from the National Oceanographic and Atmospheric Administration (BAA-95118) to D.D.R. as part of the Alaska Predator Ecosystem Experiment (APEX) research project and the Exxon Valdez Oil Spill Trustee Council Restoration Program. The DLW experimental protocol was approved by the Institutional Animal Care and Use Committee at Oregon State University. The views expressed in this paper are those of the authors and do not necessarily reflect those of the Exxon Valdez Oil Spill Trustee Council. Oregon State University, the Oregon Department of Fish and Wildlife, and the U.S. Geological Survey support the Oregon Cooperative Fish and Wildlife Research Unit.

\section{LITERATURE CITED}

Ainley DG, Ford RG, Brown ED, Suryan RM, Irons DB (2003) Prey resources, competition, and geographic structure of kittiwake colonies in Prince William Sound. Ecology 84: 709-723

Anthony JA, Roby DD, Turco KR (2000) Lipid content and energy density of forage fishes from the northern Gulf of Alaska. J Exp Mar Biol Ecol 248:53-78

Bautista LM, Tinbergen JM, Wiersma P, Kacelnik A (1998) Optimal foraging and beyond: How starlings cope with changes in food availability. Am Nat 152:543-561

Brodmann PA, Reyer HU, Bollmann K, Schlapfer AR, Rauter C (1997) The importance of food quantity and quality for reproductive performance in alpine water pipits (Anthus spinoletta). Oecologia 109:200-208

Brown ED, Moreland SM (2000) Ecological factors affecting the distribution and abundance of forage fish in Prince William Sound, Alaska; An APEX synthesis product. In: Wright BA, Duffy DC (eds) APEX project: Alaska predator ecosystem experiment in Prince William Sound and the Gulf of Alaska. Exxon Valdez oil spill restoration project 
final report (restoration project 00163T). Institute of Marine Science, University of Alaska Fairbanks, Fairbanks, AK

Bryant DM (1991) Constraints on energy expenditure by birds. Acta XX Congressus Internationalis Ornithologici, Vol IV, 1989-2001

Bryant DM, Tatner P (1988a) The cost of brood provisioning: effects of brood size and food supply. Proc Intern Ornithological Congr XIX: 364-379

Bryant DM, Tatner P (1988b) Energetics of the annual cycle of Dippers (Cinclus cinclus). Ibis 130:17-38

Burger AE, Piatt JF (1990) Flexible time budgets in breeding common murres: buffers against variable prey abundance. Stud Avian Biol 14:71-83.

Daan S, Deerenberg C, Dijkstra C (1996) Increased daily work precipitates natural death in the kestrel. J Anim Ecol 65:539-544

Davis JN, Todd PM, Bullock S (1999) Environment quality predicts parental provisioning decisions. Proc R Soc Lond B 266:1791-1797

Deerenberg C, Pen I, Dijkstra C, Arkies BJ, Visser GH, Daan $\mathrm{S}$ (1995) Parental energy expenditure in relation to manipulated brood size in the European kestrel (Falco tinnunculus). Zoology 99:39-48

Drent RH, Daan S (1980) The prudent parent: energetic adjustments in avian breeding. Ardea 68:225-252

Ford RG, Schneider DC, Ainley DG (1998) The factors that limit seabird recovery in the EVOS study area: a modeling approach. Exxon Valdez oil spill restoration project annual report (restoration project 98163Q). EVOS restoration council, Anchorage, AK

Furness RW, Bryant DM (1996) Effect of wind on field metabolic rates of breeding Northern Fulmars. Ecology 77 : 1181-1188

Fyhn M, Gabrielsen GW, NordØy ES, BØrge M, Langseth I, Bech C (2001) Individual variation in field metabolic rate of kittiwakes (Rissa tridactyla) during the chick-rearing period. Physiol Biochem Zool 74:343-355

Gabrielsen GW, Mehlum F, Nagy KA (1987) Daily energy expenditure and energy utilization of free-ranging Blacklegged Kittiwakes. Condor 89:126-132

Gabrielsen GW, Taylor JRE, Konarzewski M, Mehlum F (1991) Field and laboratory metabolism and thermoregulation in dovekies (Alle alle). Auk 108:71-78

Golet GH, Irons DB, Costa D (2000) Energy costs of chick rearing in Black-legged Kittiwakes. Can J Zool 78:982-991

Hails CJ, Bryant DM (1979) Reproductive energetics of a freeliving bird. J Anim Ecol 48:471-482

Hamer KC, Monoghan P, Uttley JD, Walton P, Burns MD (1993) The influence of food supply on the breeding ecology of kittiwakes (Rissa tridactyla) in Shetland. Ibis 135: $255-263$

Irons DB (1992) Aspects of foraging behavior and reproductive biology of the Black-legged Kittiwake. PhD dissertation, University of California, Irvine, CA

Irons DB (1998) Foraging area fidelity of individual seabirds in relation to tidal cycles and flock feeding. Ecology 79: 647-655

Jodice PGR, Lanctot RB, Gill VA, Roby DD, Hatch SA (2000) Sexing adult Black-legged Kittiwakes by DNA, behavior, and morphology. Waterbirds 23:407-417

Jodice PGR, Roby DD, Hatch SA, Gill VA, Lanctot RB, Visser GH (2002) Does food availability affect energy expenditure rates of nesting seabirds? A supplemental-feeding experiment with Black-legged Kittiwakes (Rissa tridactyla). Can J Zool 80:214-222

Jodice PGR, Roby DD, Suryan RM, Irons DB, Kaufman AM,
Turco KR, Visser GH (2003) Variation in energy expenditure among Black-legged Kittiwakes: effects of activityspecific metabolic rates and activity budgets. Physiol Biochem Zool 76:375-388

Kitaysky AS, Hunt GL Jr, Flint EN, Rubega MA, Decker MB (2000) Resource allocation in breeding seabirds: responses to fluctuations in their food supply. Mar Ecol Prog Ser 206: 283-296

Lifson N, McClintock R (1966) Theory of the use of the turnover rates of body water for measuring energy and material balance. J Theor Biol 12:46-74

Maniscalco JM, Ostrand WD, Coyle KO (1998) Selection of fish schools by flocking seabirds in Prince William Sound, Alaska. Colon Waterbirds 21:314-322

Monoghan P, Walton P, Wanless S, Uttley JD, Burns MD (1994) Effects of prey abundance on the foraging behaviour, diving efficiency, and time allocation of breeding Guillemots Uria aalgae. Ibis 136:214-222

Moreno J, Cowie RJ, Sanz JJ, Williams RSR (1995) Differential response by males and females to brood manipulations in the pied flycatcher (Ficedula hypoleuca): Energy expenditure and nestling diet. J Anim Ecol 64:721-732

Neter J, Wasserman W, Kutner MH (1990) Applied linear statistical models: regression, analysis of variance, and experimental designs. Irwin, Boston, MA

Norberg RA (1977) An ecological theory on foraging time and energetics and choice of optimal food-searching methods. J Anim Ecol 46:511-529

Norcross BL, Brown ED, Foy RJ, Frandsen M and 6 others (2001) A synthesis of the life history and ecology of juvenile Pacific herring in Prince William Sound, Alaska. Fish Oceanogr 10(Issue Suppl 1):42-57

Obst BS, Russell RW, Hunt Jr. GL, Eppley ZA, Harrison NM (1995) Foraging radii and energetics of Least Auklets (Aethia pusilla) breeding on three Bering Sea islands. Physiol Biochem Zool 68:647-672

Peterson CC, Nagy KA, Diamond J (1990) Sustained metabolic scope. Proc Natl Acad Sci 87:2324-2328

Roberts BD, Hatch SA (1993) Behavioral ecology of blacklegged kittiwakes during chick-rearing in a failing colony. Condor 95:330-342

Roby DD (1991) Diet and postnatal energetics in two convergent taxa of plankton-feeding seabirds. Auk 108:131-146

Roby DD, Jodice PGR, Turco KR (2000) Diet composition, reproductive energetics, and productivity of seabirds damaged by the Exxon Valdez oil spill. Exxon Valdez oil spill restoration project final report (restoration project 00163G). USGS - Oregon Cooperative Fish \& Wildlife Research Unit, Dept Fisheries \& Wildlife, Oregon State University, Corvallis, OR

Schoeller DA, van Santen E, Peterson DW, Dietz W, Jaspan J, Klein PD (1980) Total body water measurements in humans with ${ }^{18} \mathrm{O}$ and ${ }^{2} \mathrm{H}$ labeled water. Am J Clin Nutr 33: 2686-2693

Speakman JR (1997) Doubly labelled water: theory and practice. Chapman \& Hall, New York

Speakman JR, Visser GH, Ward S, Krol E (2001) The isotope dilution method for the evaluation of body composition. In: Speakman JR (ed) Body composition analysis of animals: A handbook of nondestructive methods. Cambridge University Press, Cambridge, p 56-98

Stearns SC (1992) The evolution of life histories. Oxford University Press, Oxford

Suryan RM, Irons DB, Benson J (2000) Prey switching and variable foraging strategies of Black-legged Kittiwakes and the effect on reproductive success. Condor 102: $374-384$ 
Suryan RM, Irons DB, Kaufman AM, Jodice PGR, Roby DD, Benson J, Brown ED (2002) Short-term fluctuations in forage fish availability and the effect on prey selection and brood-rearing in the black-legged kittiwake. Mar Ecol Prog Ser 236:273-287

Thedinga JF, Hulbert LB, Ostrand BD, Coyle KO (2000) Alaska predator ecosystem experiment in Prince William Sound and the Gulf of Alaska - forage fish assessment. Exxon Valdez oil spill restoration project final report (restoration project 00163A). National Marine Fisheries Service, Auke Bay Laboratory, Alaska Fisheries Science Center, Juneau, AK

Thompson DL, Furness RW, Monaghan P (1998) Field metabolic rates of kittiwakes (Rissa tridactyla) during incubation and chick rearing. Ardea 86:169-175

Editorial responsibility: Otto Kinne (Editor-in-Chief), Oldendorf/Luhe, Germany
Tinbergen JM, Dietz MW (1994) Parental energy expenditure during brood rearing in the great tit (Parus major) in relation to body mass, temperature, food availability and clutch size. Funct Ecol 8:563-572

Weathers WW, Sullivan KA (1989) Juvenile foraging proficiency, parental effort, and avian reproductive success. Ecol Monogr 59:223-236

Wiehn J, Korpimaki E (1997) Food limitation on brood size: Experimental evidence in the Eurasian kestrel. Ecology 78:2043-2050

Williams GC (1966) Natural selection, the costs of reproduction, and a refinement of Lack's principle. Am Nat 100:687-690

Zador SG, Piatt JF (1999) Time-budgets of common murres at a declining and increasing colony in Alaska. Condor 101: $149-152$

Submitted: March 21, 2005; Accepted: July 21, 2005 Proofs received from author(s): November 23, 2005 